\title{
Aristoteles'e Atfedilen bir Mineraloji Kitabı ve Bilim Tarihindeki Yeri
}

\section{A Mineralogical Treatise Attributed to Aristotle and its Place in the History of Science}

Gürsel Aksoy, Aristoteles'in Taşlar Kitabı - Kitâbu'l Ahcâr li-Aristâtâlîs (Inceleme - Arapça Metin - Çeviri - Yorum) (İstanbul: Büyüyenay Yayınları, 2018) (13.5x21cm., 288 sayfa, resimli) ISBN 978-605-2071-48-9.

Gaye Şahinbaş Erginöz ${ }^{1}$ (D)

Doç. Dr., İstanbul Üniversitesi, Edebiyat Fakültesi, Bilim Tarihi Bölümü, Istanbul, Türkiye

ORCID: G.S..E. 0000-0001-6951-477X

Sorumlu yazar/Corresponding author:

Gaye Şahinbaș Erginöz,

Istanbul Üniversitesi, Edebiyat Fakültesi, Bilim Tarihi Bölümü, İstanbul, Türkiye

E-posta/E-mail: gayesah@gmail.com

Başvuru/Submitted: 18.12 .2019 • Kabul/Accepted: 10.05.2020 • Online Yayın/Published Online: 03.07.2020

Atıf/Citation: Şahinbaş Erginöz, Gaye. "Aristoteles'e Atfedilen bir Mineraloji Kitabı ve Bilim Tarihindeki Yeri." Osman/ı Bilimi Araştırmaları 21, 2 (2020): 445-448. https://doi.org/10.26650/oba.661008

Kitâbu'l Ahcâr (Taşlar Kitabı), İslam bilim tarihinde mineraloji alanında yazılmış ilk ve temel eser olarak bilinir. Bugün için yazarının adı kesin bir şekilde bilinemese de önceleri Aristoteles'e atfedilen bu eserin, gerek İslam dünyasında gerekse Ortaçağ Avrupası'nda mineraloji konusunda yazılmış diğer eserleri etkilediği anlaşılmaktadır.

Gürsel Aksoy'un Kitâbu'l Ahcâr'1 incelediği bu kitap, yazarın Fatih Sultan Mehmet Vakıf Üniversitesi’nde Bilim Tarihi alanında 2016 yılında tamamladığı Aristoteles'e Atfedilen 
Kitâbu'l Ahcâr; Giriş-Çeviri-Değerlendirme başlıklı yüksek lisans tezinin genişletilmiş halidir. Yazar Gürsel Aksoy, İstanbul Üniversitesi Edebiyat Fakültesi Türk Dili ve Edebiyatı Bölümü mezunu olup, Aristoteles'e Atfedilen Kitâb'un-Nebât'ın Şamlı Nikolaos Yorumu başlıklı ikinci yüksek lisans tezini İ.Ü. Edebiyat Fakültesi Bilim Tarihi Bölümü’nde 2019 yılında tamamlamıştır. Aksoy, halen Fatih Sultan Mehmet Vakıf Üniversitesi Bilim Tarihi Bölümünde doktora programına devam etmektedir.

Aristoteles'in Taşlar Kitabı - Kitâbu'l Ahcâr li-Aristâtâlîs başlıklı kitap, önsöz, transkripsiyon alfabesi ve giriş kısımlarının yanı sıra, beş bölüm, kaynakça ve dizinden oluşmaktadır. Giriş bölümünde Antikçağda ve İslam dünyasında taşlar hakkındaki genel bilgilere ve temel kaynaklara yer verilmiş; Türkçe çeviriye hazırlık olması amacıyla konuyla ilgili bazı önemli çalışmalar tanıtılmıştır.

Birinci bölüm, iki kısımdan oluşmaktadır. "Kitâbu'l Ahcâr ve Bilim Tarihindeki Yeri" başlıklı ilk kısımda Kitâbu'l Ahcâr' ın yazarı, mütercimi ve müfessiri hakkında bilgi verilmiştir. “Kitâbu'l Ahcâr'ın Kökeni Problemi” başlıklı ikinci kısmında ise Julius Ruska, Francis Peters, Fuat Sezgin gibi bilim tarihçilerinin köken problemine bakış açıları ele alınmıştır. Ayrıca Kitâbu'l Ahcâr'ın Latince ve İbranice çevirilerine ve Arapça metnin Avrupa'da tanınmasına yer verilerek, eserin bilim tarihindeki yeri değerlendirilmiştir. Günümüzde Yunanca aslı kayıp olup, sadece Arapça tercümesi bulunan Kitâbu'l Ahcâr, gerek ilk yazıldığ dönem olarak düşünülen geç Antikçağın gerekse Arapçaya tercüme edildiği dönem olan 9. yüzyılın taşlar konusunda sahip olduğu bilgi ve yaklaşımların sentezini içermektedir. Eser, ilk yazıldığg dönemden itibaren uzun yıllar boyunca, taşlar ile ilgili literatüre önemli etki yapmıştır. İslam dünyasında taşlar konusunda yazılmış ilk eser olduğu belirtilen Kitâbu'l Ahcâr, sonraki dönemlerde mineraloji alanında yazılmış çeşitli eserlere (15. yüzyılda yazılmış olan Tuhfe-i Murâdî gibi) kaynaklık etmiştir. İçinde 700 civarında taş ve özellikleri hakkında bilgi bulunan Kitâbu'l Ahcâr sadece İslam dünyasında değil, Ortaçağdan itibaren 18. yüzyıla kadar Batı dünyasında da etkili olmuştur. Bu dönemde Avrupa'da yazılmış birçok eserde (William Gilbert'in De Magnete adlı eserinde olduğu gibi) Kitâbu'l Ahcâr' in etkilerini görmek mümkündür.

Kitabın "Nüshalar ve Çeviri” başlığını taşıyan ikinci bölümünde Türkçe çeviride izlenen yol ve kullanılan yöntemler hakkında bilgi verilmiştir. Kitâbu 'l Ahcâr'ın Türkçe tercümesinde, 'Paris Nüshası'nın (Julius Ruska tarafından yayımlanan Fransız Milli Kütüphanesi’ndeki Arapça metin) esas alındığı, yardımcı kaynak olarak da Süleymaniye Kütüphanesindeki iki Arapça yazmanın (Şehid Ali Paşa ve Ayasofya nüshaları) kullanıldığı belirtilmiştir.

Kitabın üçüncü bölümünde Kitâbu'l Ahcâr'ın Arapça metninin tıpkıbasımı bulunmaktadır. Bu metin Julius Ruska'nın, 1912 yılında yayımlanan Das Steinbuch des Aristoteles adlı kitabında yer alan metindir. 


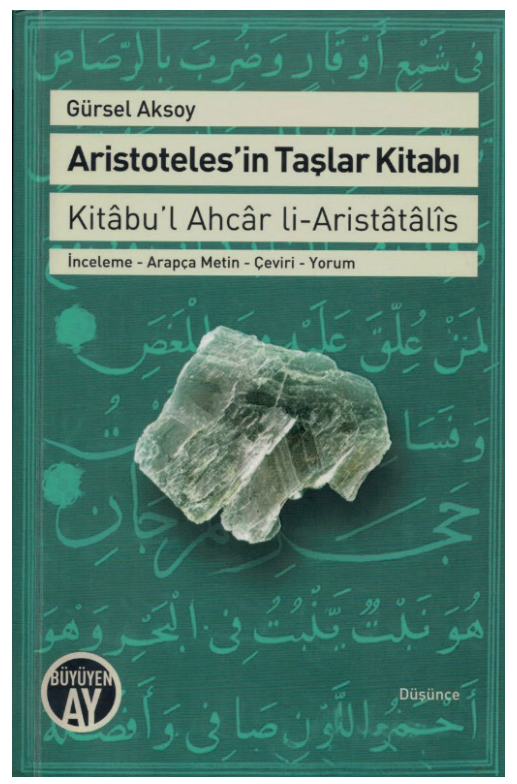

Aksoy’un kitabının "Aristoteles'in Taşlar Kitabı” başlığını taşıyan dördüncü bölümü, Kitâbu'l Ahcâr'ın bugüne kadar yapılmış ilk Türkçe tercümesini içermektedir. Çeviride, 'Paris Nüshası' kullanılmış ve Süleymaniye Kütüphanesindeki iki yazma nüsha ile karşılaştırılmıştır. Karşılaştırma sonucunda bazı farklar tespit edilmiştir. Bu çeviriye dayanarak, kitapta yer alan çeşitli taşlar hakkında bilgi verilmiştir. Bunlar arasında (adları verilmemişse de özellikleri belirtilmiş olan) gizemli taşlar, değerli taşlar (inci, yakut, elmas vb.), kimya/simya ile ilgili maddeler (kireçtaşı, markazit, tuz, soda vb.), doğaüstü taşlar (su taşı, balık taşı, uyku yapan taş vb.), tıbbi amaçlarla kullanılan taşlar (çıban taşı vb.), belirsiz taşlar (yumurta benzeri taş, çizgili taş vb.), bileşik taşlar (zincifre, bakır pası vb.) ve mıknatıslar (mıknatıs taşı, altın mıknatısı, gümüş mıknatısı vb.) bulunmaktadır. Ayrıca Şehid Ali Paşa yazmasından yapılan ekleme sonucunda, Paris nüshasında adı geçmeyen bazı taşlar (behte taşı, mürdesenk, tuğla, altın posası, petrol taşı ve idrar zorluğu taşı) ile Aristoteles'in bahsettiği yedi taşa (beyaz taş, siyah taş, sarı taş, kırmızı taş, gri taş, gök mavisi taş ve yeşil taş) da bu bölüm içinde yer verilmiştir.

Beşinci ve son bölümde ise “Çevirenin Açıklamaları” başlığı altında Kitâbu'l Ahcâr'ın Türkçe tercümesi ile ilgili yazarın kendi değerlendirme ve yorumları bulunmaktadır. Bu bölümde Kitâbu'l Ahcâr'ın içeriği antik ve İslami kaynaklarla karşılaştırılmış, metnin problemli kısımları aydınlatılmaya çalışılmıştır. Bu bölümün sonunda sadece Ayasofya yazmasında bulunan taşların listesi verilmiştir. 
Kitabın sonunda on bir fotoğraf yer almıştır. Bunlar arasında Paris, Şehid Ali Paşa ve Ayasofya nüshalarında adı geçen bazı taş ve minerallerin (boraks, mika, markazit, pirolusit vb.) müze ve koleksiyonlarda belirlenen örneklerinin fotoğrafları bulunmaktadır. "Kitâbu'l Ahcâr Yazmalarından Örnek Sayfalar” başlıklı kısımda Şehid Ali Paşa ve Ayasofya nüshalarından örnek sayfaların görsellerine yer verilmiştir. Ayrıca metinde geçen terimleri açıklayan küçük bir sözlük de hazırlanmış ve kitaba eklenmiştir. Kitabın zengin kaynakçası, yazarın çok sayıda ikincil kaynağın yanı sıra, klasik Yunanca ve Arapça kaynaklardan da yararlandığını göstermektedir.

Gürsel Aksoy bu kitabında, İslam dünyasında mineraloji alanında yazılmış ilk eser olduğu bilinen Kitâbu'l Ahcâr'1 tarihsel ve filolojik yöntemler kullanarak kapsamlı olarak incelemiştir. Bu çalışma, orijinal metnin bazı problemli yönlerini ortaya koyması, çözüm önerileri ve yorumlar getirmesi açısından özgün bir çalışmadır. Aksoy, yaptığı filolojik çalışmalar neticesinde, yazarının kimliği tartışmalı olan Kitâbu'l Ahcâr'ın Aristoteles'e ait olmadığını kesinleştirmiştir. Ancak Arapçaya tercüme edenin kimliği üzerindeki çalışmaları halen devam etmektedir. Kitâbu'l-Ahcâr'ın bilim tarihi, özellikle de mineraloji tarihi için önemli bir eser olmasına ve yabancı bilim insanları tarafından incelenmesine rağmen bugüne kadar Türkçeye tercüme edilmemiş ve yeterince incelenmemiş olması dikkat çekicidir. Aksoy, bu çalışmasında Kitâbu'l Ahcâr'ı ayrıntılı olarak inceleyerek, bu eseri kitap halinde Türkçe bilim tarihi literatürüne kazandırmıştır. 